\title{
PROFIL PERKEMBANGAN MOTORIK HALUS DAN KREATIVITAS ANAK KELOMPOK B DALAM KEGIATAN COOKING CLASS
}

\author{
Ika Anggraheni
}

\author{
PGRA Universitas Islam Malang Jl. MT. Haryono 193 Dinoyo-Malang \\ email: ika.anggraheni@unisma.ac.id
}

Diterima: 25 Mei 2019 | Direvisi: 27 Mei 2019 | Disetujui: 28 Mei 2019 (C) 2019 Pendidikan Guru Raudhatul Atfhal Fakultas Agama Islam Universitas Islam Malang

\begin{abstract}
The use of hands, fingers and eye coordination are indicators of the success of fine motor development. Creativity in children's work is the result of fine motor skills.

This research is a research with descriptive quantitative research. Data analysis techniques use descriptive with percentage. The study was conducted at Probolinggo Pembina State Kindergarten, especially for children aged 5-6 years (group B) totaling 30 children. Based on the results of these studies, this study is concluded as follows. In the variable fine motor ability indicator 1: the majority of children get a score of 4 as many as 16 children (53\%). Indicator 2: the majority of children get a score of 4 which is as many as 15 children (50\%). In indicator 3: the majority of children get a score of 4 which is as many as 18 children (60\%). Indicator 4: the majority of children get a score of 4 as many as 20 children (67\%). Indicator 5: the majority of children get a score of 4, namely 19 children (63\%).

The results on the variables of creativity development include the following. In indicator 1: the majority of children get a score of 4 which is as many as 15 children (50\%). Indicator 2: the majority of children get a score of 4 , which is 21 children (70\%). Indicator 3: the majority of children get a score of 4, which is 16 children (53\%). Indicator 4: the majority of children get a score of 4 which is as many as 18 children (60\%). Indicator 5: the majority of children get a score of 4 as many as 20 children (67\%).
\end{abstract}

Keyword: cooking class activity, fine motor development, creativity

This work is licensed under Creative Commons Attribution Non Commercial 4.0 International License Available online on: http://riset.unisma.ac.id/index.php/fai/index 


\section{A. PENDAHULUAN}

Perkembangan ilmu dan teknologi turut andil dalam perubahan paradigma pembelajaran di sekolah. Proses pelaksanaan pembelajaran yang semula bersifat behaviouristik menjadi konstruktivistik dan yang semula berpusat pada guru menjadi berpusat pada anak. Guru tidak sekedar menyampaikan pengetahuan pada anak tetapi guru juga harus dapat menstimulus agar anak dapat membentuk pengetahuan sendiri. Guru memfasilitasi anak untuk mencari tahu dan menerapkan gagasan yang dimiliki. Anak yang aktif membangun pengetahuan terus menerus lalu menyesuaikan dan mengakomodasi informasi baru. Konstruktivisme adalah teori perkembangan kognitif yang mengedepankan keaktifan anak untuk membangun pemahaman mereka tentang kenyataan.

Jaringan komunikasi dan interaksi belajar yang bermakna melalui pemberian informasi yang relevan dapat didesain oleh guru. Guru dapat memfasilitasi anak untuk mencari atau mengaplikasikan gagasan-gagasan dan mengajak anak menggunakan strategi belajar yang mereka sukai, guru menerapkan penggunaan media pembelajaran dalam mengajar, menerapkan model pembelajaran yang inovatif.

Salah satu kegiatan yang dapat dilakukan guru PAUD untuk mengembangkan motorik halus dan kreativitas adalah cooking class. Kegiatan cooking class adalah aktivitas pembelajaran memasak tanpa menggunakan api yang dapat dikerjakan oleh anak secara menyenangkan.

Menurut Hamilton (2019) kegiatan memasak dapat digunakan sebagai pembelajaran matematika dan literasi. Misalnya terdapat kegiatan menakar,menghitung,dan menghuungkan bahan yang satu dengan yang lain.

Cooking is filled with natural and authentic opportunities for learning mathematical and literacy concepts. Experimenting with measuring, counting, quantity and one-to-one correspondence are all naturally occurring learning opportunities embedded in cooking activities (Hamilton, 2019).

Menurut Cambridgeshire Community Services NHS (2018) keterampilan motorik halus merupakan kelanjutan dari pengembangan kontrol gerakan bagian-bagian tangan. Keterampilan motorik halus melibatkan otot-otot pada tubuh.

Keterampilan motorik halus melibatkan kekuatan, kontrol motorik halus, koordinasi mata tangan, sentuhan, dan ketangkasan.

Fine motor skills follow on from the development of movement control at the trunk, followed by the shoulder, then the arm, wrist, hand and fingers. Fine motor skills involve the small muscles of the body that enable such functions as writing, grasping small objects, and fastening clothing. Fine motor skills involve strength, fine motor 
control, hand eye coordination, a good sense of touch and dexterity (Cambridgeshire Community Services NHS, 2018).

Orang ykreatif lebih mudah dalam menyelesaikan permasalahan hidup dan mereka cenderung mampu hidup dengan mandiri.

People with these characteristics and experiences tend to live more fully and have more control over what happens to them because they have a creative outlook towards life (Bruce, 2004).

Sedangkan menurut Bronson (2010) menyatakan bahwa anak-anak yang mempunyai karakter kreatif lebih mudah menyelesaikan stress dan lebih percaya diri dalam menjalani hidup.

Report that children with high creative self-efficacy are better able to handle stress and are more "confident" about their futures than those who lack this characteristic (Bronson, 2010).

Kegiatan cooking class ini berupa menghias potongan pisang pada piring saji yang telah disediakan guru. Alasan memilih pisang untuk kegiatan cooking class ini adalah karena pisang merupakan salah satu jenis buah-buahan yang digemari anak karena rasanya yang manis. Selain itu, karena penelitian ini dilaksanakan di kota penghasil pisang yaitu Kota Probolinggo Jawa Timur. Dengan menyelenggarakan pembelajaran kegiatan cooking class melalui bahan (media) konkret berupa pisang harapannya agar tidak hanya dapat menarik minat anak untuk belajar, tetapi juga anak dapat mengenal potensi daerahnya.

\section{B. METODE PENELITIAN \\ 1) Jenis Penelitian}

Penelitian ini merupakan penelitian dengan jenis penelitian kuantitatif deskriptif. Adapun indikator penilaiannya sebagai berikut.

Tabel 1. Kisi-kisi Istrumen Perkembangan Motorik Halus Anak Kelompok B

\begin{tabular}{|c|c|c|}
\hline $\begin{array}{c}\text { Tingkat Pencapaian } \\
\text { Perkembangan (TPP) }\end{array}$ & $\begin{array}{c}\text { Capaian Perkembangan } \\
\text { (CP) }\end{array}$ & Indikator \\
\hline \multicolumn{2}{|c|}{ Konsep Perkembangan Motorik Halus Anak Kelompok B } \\
\hline
\end{tabular}




\begin{tabular}{|c|c|c|}
\hline $\begin{array}{l}\text { Tingkat Pencapaian } \\
\text { Perkembangan (TPP) }\end{array}$ & $\begin{array}{c}\text { Capaian Perkembangan } \\
\text { (CP) }\end{array}$ & Indikator \\
\hline Meniru bentuk & Anak mampu meniru bentuk & $\begin{array}{ll}\text { - } & \text { Menekan benda } \\
\text { - } & \text { Memotong dengan } \\
& \text { menggunakan alat } \\
\text { - } & \text { Memegang benda dengan } \\
& 5 \text { jari } \\
\text { - } & \text { Meremas benda dengan } \\
& \text { menggunakan } 5 \text { jari }\end{array}$ \\
\hline $\begin{array}{l}\text { Melakukan eksplorasi dengan } \\
\text { berbagai media dan kegiatan }\end{array}$ & $\begin{array}{l}\text { Anak mampu melakukan } \\
\text { eksplorasi dengan berbagai } \\
\text { media dan kegiatan }\end{array}$ & $\begin{array}{l}\text { Mencipta berbagai } \\
\text { bentuk yang } \\
\text { menggunakan } \\
\text { playdough/tanah } \\
\text { liat/pasir dll (menyusun } \\
\text { benda dengan kedua } \\
\text { tangan) }\end{array}$ \\
\hline
\end{tabular}

(Depdiknas, 2009)

Tabel 2. Rubrik Penilaian Perkembangan Motorik Halus

\begin{tabular}{|c|c|c|c|c|c|}
\hline \multirow{2}{*}{ Skor } & \multicolumn{5}{|c|}{ Kriteria Penilaian } \\
\hline & $\begin{array}{c}\text { Menekan } \\
\text { benda/ } \\
\text { menusuk } \\
\text { pisang } \\
\text { dengan } \\
\text { tusuk sate } \\
\text { secara } \\
\text { melintang }\end{array}$ & $\begin{array}{c}\text { Memotong } \\
\text { dengan } \\
\text { menggunakan } \\
\text { alat/ } \\
\text { memotong } \\
\text { keju dengan } \\
\text { pisau }\end{array}$ & $\begin{array}{c}\text { Memegang } \\
\text { benda } \\
\text { dengan } 5 \\
\text { jari/ } \\
\text { memberi } \\
\text { susu kental } \\
\text { manis, } \\
\text { memberi } \\
\text { topping, } \\
\text { memarut } \\
\text { keju }\end{array}$ & $\begin{array}{c}\text { Meremas benda } \\
\text { dengan } \\
\text { menggerakkan } \\
5 \text { jari/ } \\
\text { meremas choco } \\
\text { crunch }\end{array}$ & $\begin{array}{c}\text { Menyusun } \\
\text { benda } \\
\text { dengan } \\
\text { kedua } \\
\text { tangan }\end{array}$ \\
\hline$\hat{s}$ & $\begin{array}{l}\text { Anak tidak } \\
\text { mampu } \\
\text { menekan } 1 \\
\text { benda/ Anak } \\
\text { tidak mampu } \\
\text { menusuk 1 } \\
\text { pisang } \\
\text { dengan tusuk } \\
\text { sate secara } \\
\text { melintang }\end{array}$ & $\begin{array}{l}\text { Anak tidak } \\
\text { mampu } \\
\text { menggerakkan } \\
\text { alat untuk } \\
\text { memotong / Anak } \\
\text { tidak mampu } \\
\text { memotong keju } \\
\text { dengan pisau }\end{array}$ & $\begin{array}{l}\text { Anak tidak } \\
\text { mampu } \\
\text { memegang } 1 \\
\text { jenis benda } \\
\text { apa pun }\end{array}$ & $\begin{array}{l}\text { Anak tidak mampu } \\
\text { menggerakkan } 5 \\
\text { jari untuk } \\
\text { meremas choco } \\
\text { crunch }\end{array}$ & $\begin{array}{l}\text { Anak tidak } \\
\text { mampu } \\
\text { menyusun } \\
\text { benda dengan } \\
\text { kedua tangan } \\
\text { secara sejajar }\end{array}$ \\
\hline
\end{tabular}




\begin{tabular}{|c|c|c|c|c|c|}
\hline \multirow[t]{2}{*}{ Skor } & \multicolumn{5}{|c|}{ Kriteria Penilaian } \\
\hline & $\begin{array}{l}\text { Menekan } \\
\text { benda/ } \\
\text { menusuk } \\
\text { pisang } \\
\text { dengan } \\
\text { tusuk sate } \\
\text { secara } \\
\text { melintang }\end{array}$ & $\begin{array}{c}\text { Memotong } \\
\text { dengan } \\
\text { menggunakan } \\
\text { alat/ } \\
\text { memotong } \\
\text { keju dengan } \\
\text { pisau }\end{array}$ & $\begin{array}{c}\text { Memegang } \\
\text { benda } \\
\text { dengan } 5 \\
\text { jari/ } \\
\text { memberi } \\
\text { susu kental } \\
\text { manis, } \\
\text { memberi } \\
\text { topping, } \\
\text { memarut } \\
\text { keju }\end{array}$ & $\begin{array}{c}\text { Meremas benda } \\
\text { dengan } \\
\text { menggerakkan } \\
5 \text { jari/ } \\
\text { meremas choco } \\
\text { crunch }\end{array}$ & $\begin{array}{l}\text { Menyusun } \\
\text { benda } \\
\text { dengan } \\
\text { kedua } \\
\text { tangan }\end{array}$ \\
\hline$\hat{\psi} \hat{\psi}$ & $\begin{array}{l}\text { Anak mampu } \\
\text { menekan } 1 \\
\text { benda/ Anak } \\
\text { mampu } \\
\text { menusuk } 1 \\
\text { pisang } \\
\text { dengan tusuk } \\
\text { sate secara } \\
\text { melintang }\end{array}$ & $\begin{array}{l}\text { Anak mampu } \\
\text { menggerakkan } \\
\text { alat untuk } \\
\text { memotong } 1 \\
\text { benda/ Anak } \\
\text { mampu } \\
\text { menggerakkan } \\
\text { pisau untuk } \\
\text { memotong } 1 \\
\text { potongan keju }\end{array}$ & $\begin{array}{l}\text { Anak mampu } \\
\text { memegang } 1 \\
\text { jenis benda }\end{array}$ & $\begin{array}{l}\text { Anak mampu } \\
\text { menggerakkan } 5 \\
\text { jari (kurang dari } 5 \\
\text { gerakan) untuk } \\
\text { meremas choco } \\
\text { crunch }\end{array}$ & $\begin{array}{l}\text { Anak mampu } \\
\text { menyusun } \\
\text { benda } \\
\text { menggunakan } \\
\text { kedua tangan } \\
\text { secara sejajar } \\
\text { tetapi belum } \\
\text { rapi melalui } \\
\text { bantuan guru }\end{array}$ \\
\hline$\hat{\psi} \dot{w}$ & $\begin{array}{l}\text { Anak mampu } \\
\text { menekan } 2 \\
\text { benda atau } \\
\text { lebih dengan } \\
\text { bantuan } \\
\text { guru/ Anak } \\
\text { mampu } \\
\text { menusuk } 2 \\
\text { pisang atau } \\
\text { lebih dengan } \\
\text { tusuk sate } \\
\text { secara } \\
\text { melintang } \\
\text { dengan } \\
\text { bantuan guru }\end{array}$ & $\begin{array}{l}\text { Anak mampu } \\
\text { menggerakkan } \\
\text { alat untuk } \\
\text { memotong lebih } \\
\text { dari } 1 \text { benda } \\
\text { dengan bantuan } \\
\text { guru/ Anak } \\
\text { mampu } \\
\text { menggerakkan } \\
\text { pisau untuk } \\
\text { memotong lebih } \\
\text { dari 1 potongan } \\
\text { keju dengan } \\
\text { bantuan guru }\end{array}$ & $\begin{array}{l}\text { Anak mampu } \\
\text { memegang } 2 \\
\text { jenis benda } \\
\text { atau lebih } \\
\text { dengan } \\
\text { bantuan guru }\end{array}$ & $\begin{array}{l}\text { Anak mampu } \\
\text { menggerakkan } 5 \\
\text { jari (lebih dari } 5 \\
\text { gerakan) untuk } \\
\text { meremas choco } \\
\text { crunch dengan } \\
\text { bantuan guru }\end{array}$ & $\begin{array}{l}\text { Anak mampu } \\
\text { menyusun } \\
\text { benda } \\
\text { menggunakan } \\
\text { kedua tangan } \\
\text { secara sejajar } \\
\text { dengan rapi } \\
\text { melalui } \\
\text { bantuan guru }\end{array}$ \\
\hline 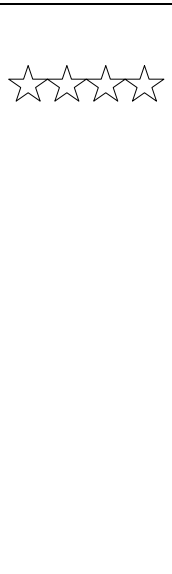 & $\begin{array}{l}\text { Anak mampu } \\
\text { menekan } 2 \\
\text { benda atau } \\
\text { lebih secara } \\
\text { mandiri/ } \\
\text { Anak mampu } \\
\text { menusuk } 2 \\
\text { pisang atau } \\
\text { lebih dengan } \\
\text { tusuk sate } \\
\text { secara } \\
\text { melintang } \\
\text { dengan } \\
\text { mandiri }\end{array}$ & $\begin{array}{l}\text { Anak mampu } \\
\text { menggerakkan } \\
\text { alat untuk } \\
\text { memotong lebih } \\
\text { dari } 1 \text { benda } \\
\text { secara mandiri/ } \\
\text { Anak mampu } \\
\text { menggerakkan } \\
\text { pisau untuk } \\
\text { memotong lebih } \\
\text { dari } 1 \text { potongan } \\
\text { keju secara } \\
\text { mandiri }\end{array}$ & $\begin{array}{l}\text { Anak mampu } \\
\text { memegang } 2 \\
\text { jenis } \\
\text { bendaatau } \\
\text { lebih tanpa } \\
\text { bantuan guru }\end{array}$ & $\begin{array}{l}\text { Anak mampu } \\
\text { menggerakkan } 5 \\
\text { jari (lebih dari } 5 \\
\text { gerakan) untuk } \\
\text { meremas choco } \\
\text { crunch tanpa } \\
\text { bantuan guru }\end{array}$ & $\begin{array}{l}\text { Anak mampu } \\
\text { menyusun } \\
\text { benda } \\
\text { menggunakan } \\
\text { kedua tangan } \\
\text { secara sejajar } \\
\text { dengan rapi } \\
\text { tanpa bantuan } \\
\text { guru }\end{array}$ \\
\hline
\end{tabular}


Tabel 3. Rubrik Penilaian Kreativitas

\begin{tabular}{|c|c|c|c|c|c|}
\hline \multirow[t]{2}{*}{ Skor } & \multicolumn{5}{|c|}{ Kriteria } \\
\hline & $\begin{array}{c}\text { Menemukan } \\
\text { ide untuk } \\
\text { menghasilkan } \\
\text { suatu karya }\end{array}$ & $\begin{array}{c}\text { Membuat } \\
\text { bentuk dari } \\
\text { benda yang } \\
\text { disediakan }\end{array}$ & $\begin{array}{c}\text { Menghias } \\
\text { bentuk }\end{array}$ & $\begin{array}{c}\text { Menciptakan } \\
\text { sajian yang } \\
\text { berbeda dari } \\
\text { temannya }\end{array}$ & $\begin{array}{c}\text { Memberi } \\
\text { nama } \\
\text { hasil } \\
\text { karya } \\
\text { yang } \\
\text { dibuat }\end{array}$ \\
\hline 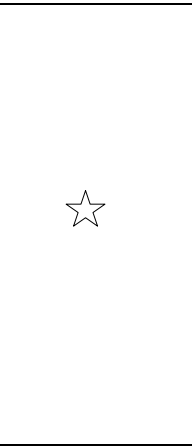 & $\begin{array}{l}\text { Anak tidak } \\
\text { menemukan ide } \\
1 \text { pun untuk } \\
\text { menghasilkan } \\
\text { suatu karya }\end{array}$ & $\begin{array}{l}\text { Anak belum } \\
\text { mampu } \\
\text { membuat } 1 \\
\text { bentuk pun } \\
\text { dari benda } \\
\text { yang } \\
\text { disediakan }\end{array}$ & $\begin{array}{l}\text { Anak mampu } \\
\text { menghias } \\
\text { bentuk } \\
\text { dengan } \\
\text { menggunakan } \\
1 \text { bahan } \\
\text { (media) }\end{array}$ & $\begin{array}{l}\text { Anakbelum } \\
\text { mampu } \\
\text { menciptakan } \\
\text { karya yang } \\
\text { berbeda dari } \\
\text { temannya } \\
\text { (masih } \\
\text { sama/meniru } \\
\text { temannya) }\end{array}$ & $\begin{array}{l}\text { Anak } \\
\text { belum } \\
\text { mampu } \\
\text { memberi } \\
\text { nama } \\
\text { hasil } \\
\text { karya } \\
\text { yang } \\
\text { dibuat }\end{array}$ \\
\hline$\hat{z} \hat{s}$ & $\begin{array}{l}\text { Anak } \\
\text { menemukan } 1 \\
\text { ide untuk } \\
\text { menghasilkan } \\
\text { suatu } \\
\text { karyadengan } \\
\text { bantuan guru }\end{array}$ & $\begin{array}{l}\text { Anak mampu } \\
\text { membuat } 1 \\
\text { bentuk dari } \\
\text { benda yang } \\
\text { disediakan } \\
\text { dengan } \\
\text { bantuan guru }\end{array}$ & $\begin{array}{l}\text { Anak mampu } \\
\text { menghias } \\
\text { bentuk } \\
\text { dengan } \\
\text { kombinasi } 2 \\
\text { bahan } \\
\text { (media) tetapi } \\
\text { masih dibantu } \\
\text { guru }\end{array}$ & $\begin{array}{l}\text { Anak mampu } \\
\text { menciptakan } 1 \\
\text { karya yang } \\
\text { berbeda dari } \\
\text { temannya } \\
\text { dengan } \\
\text { bantuan guru }\end{array}$ & $\begin{array}{l}\text { Anak } \\
\text { mampu } \\
\text { memberi } \\
\text { nama } \\
\text { untuk } 1 \\
\text { hasil } \\
\text { karya } \\
\text { yang } \\
\text { dibuat } \\
\text { dengan } \\
\text { bantuan } \\
\text { guru }\end{array}$ \\
\hline$\hat{4} \hat{4} \vec{s}$ & $\begin{array}{l}\text { Anak } \\
\text { menemukan } 1 \\
\text { ide untuk } \\
\text { menghasilkan } \\
\text { suatu karya } \\
\text { secara mandiri }\end{array}$ & $\begin{array}{l}\text { Anak mampu } \\
\text { membuat } 1 \\
\text { bentuk dari } \\
\text { benda yang } \\
\text { disediakan } \\
\text { secara } \\
\text { mandiri }\end{array}$ & $\begin{array}{l}\text { Anak mampu } \\
\text { menghias } \\
\text { bentuk } \\
\text { dengan } \\
\text { kombinasi } 2 \\
\text { bahan } \\
\text { (media) } \\
\text { secara } \\
\text { mandiri }\end{array}$ & $\begin{array}{l}\text { Anak mampu } \\
\text { menciptakan } 1 \\
\text { karya yang } \\
\text { berbeda dari } \\
\text { temannya } \\
\text { secara mandiri }\end{array}$ & $\begin{array}{l}\text { Anak } \\
\text { mampu } \\
\text { memberi } \\
\text { nama } \\
\text { untuk } 1 \\
\text { hasil } \\
\text { karya } \\
\text { yang } \\
\text { dibuat } \\
\text { secara } \\
\text { mandiri }\end{array}$ \\
\hline 2 & $\begin{array}{l}\text { Anak } \\
\text { menemukan }\end{array}$ & $\begin{array}{l}\text { Anak mampu } \\
\text { membuat }\end{array}$ & $\begin{array}{l}\text { Anak mampu } \\
\text { menghias }\end{array}$ & $\begin{array}{l}\text { Anak mampu } \\
\text { menciptakan }\end{array}$ & $\begin{array}{l}\text { Anak } \\
\text { mampu }\end{array}$ \\
\hline
\end{tabular}




\begin{tabular}{|c|c|c|c|c|c|}
\hline \multirow[t]{2}{*}{ Skor } & \multicolumn{5}{|c|}{ Kriteria } \\
\hline & $\begin{array}{l}\text { Menemukan } \\
\text { ide untuk } \\
\text { menghasilkan } \\
\text { suatu karya }\end{array}$ & $\begin{array}{c}\text { Membuat } \\
\text { bentuk dari } \\
\text { benda yang } \\
\text { disediakan }\end{array}$ & $\begin{array}{l}\text { Menghias } \\
\text { bentuk }\end{array}$ & $\begin{array}{c}\text { Menciptakan } \\
\text { sajian yang } \\
\text { berbeda dari } \\
\text { temannya }\end{array}$ & $\begin{array}{c}\text { Memberi } \\
\text { nama } \\
\text { hasil } \\
\text { karya } \\
\text { yang } \\
\text { dibuat }\end{array}$ \\
\hline & $\begin{array}{l}\text { lebih dari } 1 \text { ide } \\
\text { untuk } \\
\text { menghasilkan } \\
\text { suatu karya } \\
\text { secara mandiri }\end{array}$ & $\begin{array}{l}\text { lebih dari } 1 \\
\text { bentuk } \\
\text { menggunakan } \\
\text { benda yang } \\
\text { disediakan } \\
\text { secara } \\
\text { mandiri }\end{array}$ & $\begin{array}{l}\text { bentuk } \\
\text { dengan } \\
\text { kombinasi } \\
\text { lebih dari } 2 \\
\text { bahan } \\
\text { (media) } \\
\text { secara } \\
\text { mandiri }\end{array}$ & $\begin{array}{l}\text { lebih dari } 1 \\
\text { karya yang } \\
\text { berbeda dari } \\
\text { temannya } \\
\text { secara mandiri }\end{array}$ & $\begin{array}{l}\text { memberi } \\
\text { nama } \\
\text { untuk } \\
\text { lebih dari } \\
1 \text { hasil } \\
\text { karya } \\
\text { yang } \\
\text { dibuat } \\
\text { secara } \\
\text { mandiri }\end{array}$ \\
\hline
\end{tabular}

\section{2) Teknik analisis data}

Teknik analisis data menggunakan analisis deksriptif dengan persentase untuk mengetahui profil perkembangan motorik halus dan kreativitas anak kelompok B. Rumus yang digunakan sebagai berikut.

$$
\mathrm{P}=\frac{F}{N} \times 100 \%
$$

Keterangan:

$\mathrm{P}=$ persentase yang dicari

$F=$ frekuensi

$N=$ jumlah responden

\section{HASIL DAN PEMBAHASAN}

1. Hasil Penelitian Profil Perkembangan Motorik Halus Anak Kelompok B

Penelitian ini merupakan penelitian deskriptif, sehingga hasil penelitian tentang profil perkembangan soaial anak kelompok B TK Negeri Pembina, perlu dideksripsikan secara menyeluruh maupun setiap indikator. Adapun hasil penelitian setiap indikator diperoleh data sebagai berikut. 
Tabel 4. Profil perkembangan motorik halus anak indikator 1

\begin{tabular}{|c|c|c|c|}
\hline Skor & Kriteria Penilaian & Frekuensi & Persentase \\
\hline \multicolumn{4}{|c|}{ Menekan benda/ menusuk pisang dengan tusuk sate secara melintang } \\
\hline $\begin{array}{l}\text { (1) } \\
\Sigma\end{array}$ & $\begin{array}{l}\text { Anak tidak mampu } \\
\text { menekan } 1 \text { benda/ Anak } \\
\text { tidak mampu menusuk } 1 \\
\text { pisang dengan tusuk sate } \\
\text { secara melintang }\end{array}$ & 3 & $10 \%$ \\
\hline $\begin{array}{c}(2) \\
\dot{w} \hat{z}\end{array}$ & $\begin{array}{l}\text { Anak mampu menekan } 1 \\
\text { benda/ Anak mampu } \\
\text { menusuk } 1 \text { pisang dengan } \\
\text { tusuk sate secara } \\
\text { melintang }\end{array}$ & 5 & $17 \%$ \\
\hline$\hat{z} \hat{z} \hat{z}$ & $\begin{array}{l}\text { Anak mampu menekan } 2 \\
\text { benda atau lebih dengan } \\
\text { bantuan guru/ Anak } \\
\text { mampu menusuk } 2 \text { pisang } \\
\text { atau lebih dengan tusuk } \\
\text { sate secara melintang } \\
\text { dengan bantuan guru }\end{array}$ & 6 & $20 \%$ \\
\hline 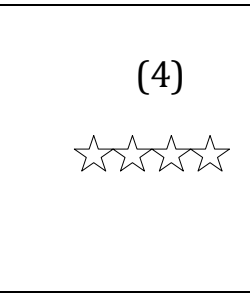 & $\begin{array}{l}\text { Anak mampu menekan } 2 \\
\text { benda atau lebih secara } \\
\text { mandiri/ Anak mampu } \\
\text { menusuk } 2 \text { pisang atau } \\
\text { lebih dengan tusuk sate } \\
\text { secara melintang dengan } \\
\text { mandiri }\end{array}$ & 16 & $53 \%$ \\
\hline
\end{tabular}

Pada variabel kemampuan motorik halus indikator 1: mayoritas anak mendapatkan skor 4 yaitu sebanyak 16 anak (53\%) yang berarti mayoritas anak mampu menusuk 2 pisang atau lebih dengan tusuk sate secara melintang dengan mandiri.

Tabel 5. Profil perkembangan motorik halus anak indikator 2

\begin{tabular}{|c|l|l|l|}
\hline Skor & \multicolumn{1}{|c|}{ Kriteria Penilaian } & Frekuensi & Persentase \\
\hline $\begin{array}{c}\text { Memotong dengan menggunakan alat/ memotong keju dengan } \\
\text { pisau }\end{array}$ & $\begin{array}{l}\text { Anak tidak mampu } \\
\text { menggerakkan alat untuk } \\
\text { memotong / Anak tidak } \\
\text { mampu memotong keju } \\
\text { dengan pisau }\end{array}$ & 4 & $13 \%$ \\
\hline$(2)$ & Anak mampu & 5 & $17 \%$ \\
\hline
\end{tabular}




\begin{tabular}{|c|c|c|c|}
\hline$\hat{w} \vec{w}$ & $\begin{array}{l}\text { menggerakkan alat untuk } \\
\text { memotong } 1 \text { benda/ Anak } \\
\text { mampu menggerakkan } \\
\text { pisau untuk memotong } 1 \\
\text { potongan keju }\end{array}$ & & \\
\hline 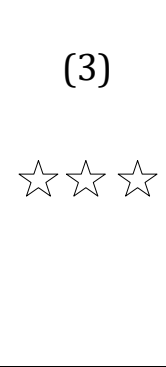 & $\begin{array}{l}\text { Anak mampu } \\
\text { menggerakkan alat untuk } \\
\text { memotong lebih dari } 1 \\
\text { benda dengan bantuan } \\
\text { guru/ Anak mampu } \\
\text { menggerakkan pisau } \\
\text { untuk memotong lebih } \\
\text { dari } 1 \text { potongan keju } \\
\text { dengan bantuan guru }\end{array}$ & 6 & $20 \%$ \\
\hline 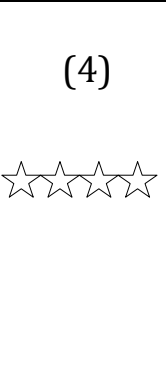 & $\begin{array}{l}\text { Anak mampu } \\
\text { menggerakkan alat untuk } \\
\text { memotong lebih dari } 1 \\
\text { benda secara mandiri/ } \\
\text { Anak mampu } \\
\text { menggerakkan pisau } \\
\text { untuk memotong lebih } \\
\text { dari } 1 \text { potongan keju } \\
\text { secara mandiri }\end{array}$ & 15 & $50 \%$ \\
\hline
\end{tabular}

Pada variabel kemampuan motorik halus indikator 2: mayoritas anak mendapatkan skor 4 yaitu sebanyak 15 anak (50\%) yang berarti mayoritas Anak mampu menggerakkan alat untuk memotong lebih dari 1 benda secara mandiri/ anak mampu menggerakkan pisau untuk memotong lebih dari 1 potongan keju secara mandiri.

Tabel 6. Profil perkembangan motorik halus anak indikator 3

\begin{tabular}{|c|c|c|c|}
\hline Skor & Kriteria Penilaian & Frekuensi & Persentase \\
\hline \multicolumn{4}{|c|}{$\begin{array}{l}\text { Memegang benda dengan } 5 \text { jari/ memberi susu kental manis, } \\
\text { memberi topping, memarut keju }\end{array}$} \\
\hline$\hat{s}$ & $\begin{array}{l}\text { Anak tidak mampu } \\
\text { memegang } 1 \text { jenis benda } \\
\text { apa pun }\end{array}$ & 0 & $0 \%$ \\
\hline (2) & $\begin{array}{l}\text { Anak mampu memegang } \\
1 \text { jenis benda }\end{array}$ & 5 & $17 \%$ \\
\hline
\end{tabular}




\begin{tabular}{|c|c|c|c|}
\hline Skor & Kriteria Penilaian & Frekuensi & Persentase \\
\hline \multicolumn{4}{|c|}{$\begin{array}{l}\text { Memegang benda dengan } 5 \text { jari/ memberi susu kental manis, } \\
\text { memberi topping, memarut keju }\end{array}$} \\
\hline $\begin{array}{c}\hat{w} \hat{z} \hat{r} \\
\text { (3) }\end{array}$ & $\begin{array}{l}\text { Anak mampu memegang } \\
2 \text { jenis benda atau lebih } \\
\text { dengan bantuan guru }\end{array}$ & 7 & $23 \%$ \\
\hline $\begin{array}{l}\text { (4) } \\
\text { (4) }\end{array}$ & $\begin{array}{l}\text { Anak mampu memegang } \\
2 \text { jenis bendaatau lebih } \\
\text { tanpa bantuan guru }\end{array}$ & 18 & $60 \%$ \\
\hline
\end{tabular}

Pada variabel kemampuan motorik halus indikator 3: mayoritas anak mendapatkan skor 4 yaitu sebanyak 18 anak (60\%) yang berarti mayoritas Anak mampu memegang 2 jenis bendaatau lebih tanpa bantuan guru.

Tabel 7. Profil perkembangan motorik halus anak indikator 4

\begin{tabular}{|c|c|c|c|}
\hline Skor & Kriteria Penilaian & Frekuensi & Persentase \\
\hline \multicolumn{4}{|c|}{$\begin{array}{l}\text { Meremas benda dengan menggerakkan } 5 \text { jari/ meremas choco } \\
\text { crunch }\end{array}$} \\
\hline $\begin{array}{l}\sum \\
(1)\end{array}$ & $\begin{array}{l}\text { Anak tidak mampu } \\
\text { menggerakkan } 5 \text { jari } \\
\text { untuk meremas choco } \\
\text { crunch }\end{array}$ & 1 & $3 \%$ \\
\hline 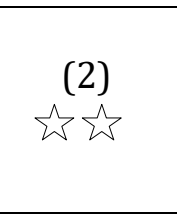 & $\begin{array}{l}\text { Anak mampu } \\
\text { menggerakkan } 5 \text { jari } \\
\text { (kurang dari } 5 \text { gerakan) } \\
\text { untuk meremas choco } \\
\text { crunch }\end{array}$ & 2 & $7 \%$ \\
\hline $\begin{array}{c}(3) \\
\dot{w} \hat{s} \hat{z}\end{array}$ & $\begin{array}{l}\text { Anak mampu } \\
\text { menggerakkan } 5 \text { jari } \\
\text { (lebih dari } 5 \text { gerakan) } \\
\text { untuk meremas choco } \\
\text { crunch dengan bantuan } \\
\text { guru }\end{array}$ & 7 & $23 \%$ \\
\hline 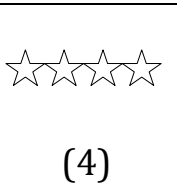 & $\begin{array}{l}\text { Anak mampu memegang } \\
2 \text { jenis bendaatau lebih } \\
\text { tanpa bantuan guru }\end{array}$ & 20 & $67 \%$ \\
\hline
\end{tabular}


Pada variabel kemampuan motorik halus indikator 4: mayoritas anak mendapatkan skor 4 yaitu sebanyak 20 anak (67\%) yang berarti mayoritas anak mampu memegang 2 jenis bendaatau lebih tanpa bantuan guru.

Tabel 8. Profil perkembangan motorik halus anak indikator 5

\begin{tabular}{|c|c|c|c|}
\hline Skor & Kriteria Penilaian & Frekuensi & Persentase \\
\hline \multicolumn{4}{|c|}{ Menyusun benda dengan kedua tangan } \\
\hline (1) & $\begin{array}{l}\text { Anak tidak mampu } \\
\text { menyusun benda dengan } \\
\text { kedua tangan secara sejajar }\end{array}$ & 1 & $3 \%$ \\
\hline $\begin{array}{l}(2) \\
\hat{\omega} \hat{s}\end{array}$ & $\begin{array}{l}\text { Anak mampu menyusun } \\
\text { benda menggunakan kedua } \\
\text { tangan secara sejajar tetapi } \\
\text { belum rapi melalui bantuan } \\
\text { guru }\end{array}$ & 2 & $6 \%$ \\
\hline $\begin{array}{l}(3) \\
\hat{w} \hat{s} \hat{s}\end{array}$ & $\begin{array}{l}\text { Anak mampu menyusun } \\
\text { benda menggunakan kedua } \\
\text { tangan secara sejajar } \\
\text { dengan rapi melalui } \\
\text { bantuan guru }\end{array}$ & 8 & $27 \%$ \\
\hline 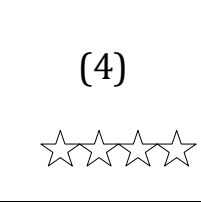 & $\begin{array}{l}\text { Anak mampu menyusun } \\
\text { benda menggunakan kedua } \\
\text { tangan secara sejajar } \\
\text { dengan rapi tanpa bantuan } \\
\text { guru }\end{array}$ & 19 & $63 \%$ \\
\hline
\end{tabular}

Pada variabel kemampuan motorik halus indikator 4: mayoritas anak mendapatkan skor 4 yaitu sebanyak 19 anak (63\%) yang berarti mayoritas anak mampu menyusun benda menggunakan kedua tangan secara sejajar dengan rapi tanpa bantuan guru.

\section{Hasil Penelitian Profil Perkembangan Kreativitas Anak Kelompok B}

Tabel 9. Profil perkembangan kreativitas anak indikator 1

\begin{tabular}{|l|l|l|l|}
\hline Skor & Kriteria Penilaian & Frekuensi & Persentase \\
\hline \multicolumn{3}{|c|}{ Menemukan ide untuk menghasilkan suatu karya } \\
\hline & $\begin{array}{l}\text { Anak tidak } \\
\text { menemukan ide 1 } \\
\text { pun untuk }\end{array}$ & 1 & $3 \%$ \\
$(1) \leftarrow\}$
\end{tabular}




\begin{tabular}{|c|c|c|c|}
\hline Skor & Kriteria Penilaian & Frekuensi & Persentase \\
\hline & $\begin{array}{l}\text { menghasilkan } \\
\text { suatu karya }\end{array}$ & & \\
\hline $\begin{array}{l}(2) \\
\hat{\imath} \hat{\imath}\end{array}$ & $\begin{array}{l}\text { Anak menemukan } \\
1 \text { ide untuk } \\
\text { menghasilkan } \\
\text { suatu karyadengan } \\
\text { bantuan guru }\end{array}$ & 5 & $17 \%$ \\
\hline $\begin{array}{c}(3) \\
\dot{w} \vec{s} \vec{s}\end{array}$ & $\begin{array}{l}\text { Anak menemukan } \\
1 \text { ide untuk } \\
\text { menghasilkan } \\
\text { suatu karya secara } \\
\text { mandiri }\end{array}$ & 9 & $30 \%$ \\
\hline 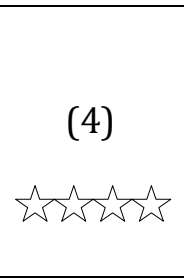 & $\begin{array}{l}\text { Anak menemukan } \\
\text { lebih dari } 1 \text { ide } \\
\text { untuk } \\
\text { menghasilkan } \\
\text { suatu karya secara } \\
\text { mandiri }\end{array}$ & 15 & $50 \%$ \\
\hline
\end{tabular}

Pada variabel perkembangan kreativitas anak indikator 1: mayoritas anak mendapatkan skor 4 yaitu sebanyak 15 anak (50\%) yang berarti mayoritas anak menemukan lebih dari 1 ide untuk menghasilkan suatu karya secara mandiri.

Tabel 10. Profil perkembangan kreativitas anak indikator 2

\begin{tabular}{|c|c|c|c|}
\hline Skor & Kriteria Penilaian & Frekuensi & Persentase \\
\hline \multicolumn{4}{|c|}{ Membuat bentuk dari benda yang disediakan } \\
\hline$\sum$ & $\begin{array}{l}\text { Anak belum mampu } \\
\text { membuat } 1 \text { bentuk pun } \\
\text { dari benda yang } \\
\text { disediakan }\end{array}$ & 0 & $0 \%$ \\
\hline $\begin{array}{l}(2) \\
\hat{s} \boldsymbol{t}\end{array}$ & $\begin{array}{l}\text { Anak mampu membuat } \\
1 \text { bentuk dari benda } \\
\text { yang disediakan } \\
\text { dengan bantuan guru }\end{array}$ & 1 & $3 \%$ \\
\hline $\begin{array}{c}(3) \\
\hat{z}^{\wedge} \hat{z} \vec{k}\end{array}$ & $\begin{array}{l}\text { Anak mampu membuat } \\
1 \text { bentuk dari benda } \\
\text { yang disediakan secara } \\
\text { mandiri }\end{array}$ & 8 & $27 \%$ \\
\hline intris & $\begin{array}{l}\text { Anak mampu membuat } \\
\text { lebih dari } 1 \text { bentuk }\end{array}$ & 21 & $70 \%$ \\
\hline
\end{tabular}




\begin{tabular}{|c|l|c|c|}
\hline Skor & Kriteria Penilaian & Frekuensi & Persentase \\
\hline$(4)$ & $\begin{array}{l}\text { menggunakan benda } \\
\text { yang disediakan secara } \\
\text { mandiri }\end{array}$ & & \\
\hline
\end{tabular}

Pada variabel perkembangan kreativitas anak indikator 2: mayoritas anak mendapatkan skor 4 yaitu sebanyak 21 anak (70\%) yang berarti mayoritas anak mampu membuat lebih dari 1 bentuk menggunakan benda yang disediakan secara mandiri.

Tabel 11. Profil perkembangan kreativitas anak indikator 3

\begin{tabular}{|c|c|c|c|}
\hline Skor & Kriteria Penilaian & Frekuensi & Persentase \\
\hline \multicolumn{4}{|c|}{ Menghias bentuk } \\
\hline$\hat{w}$ & $\begin{array}{l}\text { Anak mampu menghias } \\
\text { bentuk dengan } \\
\text { menggunakan } 1 \text { bahan } \\
\text { (media) }\end{array}$ & 4 & $13 \%$ \\
\hline 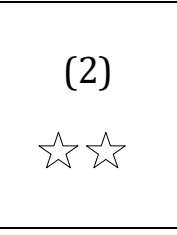 & $\begin{array}{l}\text { Anak mampu menghias } \\
\text { bentuk dengan } \\
\text { kombinasi } 2 \text { bahan } \\
\text { (media) tetapi masih } \\
\text { dibantu guru }\end{array}$ & 5 & $17 \%$ \\
\hline $\begin{array}{c}(3) \\
\dot{z} \hat{z} \dot{z}\end{array}$ & $\begin{array}{l}\text { Anak mampu menghias } \\
\text { bentuk dengan } \\
\text { kombinasi } 2 \text { bahan } \\
\text { (media) secara mandiri }\end{array}$ & 5 & $17 \%$ \\
\hline $\begin{array}{l}\text { (4) } \\
\text { (4) }\end{array}$ & $\begin{array}{l}\text { Anak mampu menghias } \\
\text { bentuk dengan } \\
\text { kombinasi lebih dari } 2 \\
\text { bahan (media) secara } \\
\text { mandiri }\end{array}$ & 16 & $53 \%$ \\
\hline
\end{tabular}

Pada variabel perkembangan kreativitas anak indikator 3: mayoritas anak mendapatkan skor 4 yaitu sebanyak 16 anak (53\%) yang berarti mayoritas mampu menghias bentuk dengan kombinasi lebih dari 2 bahan (media) secara mandiri. 
Tabel 12. Profil perkembangan kreativitas anak indikator 4

\begin{tabular}{|c|c|c|c|}
\hline Skor & Kriteria Penilaian & Frekuensi & Persentase \\
\hline \multicolumn{4}{|c|}{ Menciptakan saiian yang berbeda dari temannya } \\
\hline $\begin{array}{l}\text { (1) } \\
\lambda^{2}\end{array}$ & $\begin{array}{l}\text { Anak belum mampu } \\
\text { menciptakan karya } \\
\text { yang berbeda dari } \\
\text { temannya (masih } \\
\text { sama/meniru } \\
\text { temannya) }\end{array}$ & 2 & $7 \%$ \\
\hline $\begin{array}{l}\text { (2) } \\
\dot{s} \hat{s}\end{array}$ & $\begin{array}{l}\text { Anak mampu } \\
\text { menciptakan } 1 \text { karya } \\
\text { yang berbeda dari } \\
\text { temannya dengan } \\
\text { bantuan guru }\end{array}$ & 1 & $3 \%$ \\
\hline 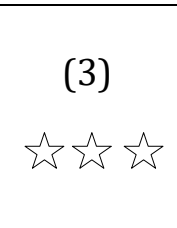 & $\begin{array}{l}\text { Anak mampu } \\
\text { menciptakan } 1 \text { karya } \\
\text { yang berbeda dari } \\
\text { temannya secara } \\
\text { mandiri }\end{array}$ & 9 & $30 \%$ \\
\hline 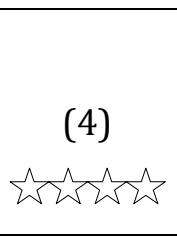 & $\begin{array}{l}\text { Anak mampu } \\
\text { menciptakan lebih dari } \\
1 \text { karya yang berbeda } \\
\text { dari temannya secara } \\
\text { mandiri }\end{array}$ & 18 & $60 \%$ \\
\hline
\end{tabular}

Pada variabel perkembangan kreativitas anak indikator 4: mayoritas anak mendapatkan skor 4 yaitu sebanyak 18 anak (60\%) yang berarti mayoritas anak mampu menciptakan lebih dari 1 karya yang berbeda dari temannya secara mandiri.

Tabel 13. Profil perkembangan kreativitas anak indikator 5

\begin{tabular}{|c|c|c|c|}
\hline Skor & Kriteria Penilaian & Frekuensi & Persentase \\
\hline \multicolumn{4}{|c|}{ Memberi nama hasil karya yang dibuat } \\
\hline $\begin{array}{l}\hat{3} \\
\text { (1) }\end{array}$ & $\begin{array}{l}\text { Anak belum mampu } \\
\text { memberi nama hasil } \\
\text { karya yang dibuat }\end{array}$ & 3 & $10 \%$ \\
\hline $\begin{array}{l}(2) \\
\hat{\imath} \vec{k}\end{array}$ & $\begin{array}{l}\text { Anak mampu } \\
\text { memberi nama untuk } \\
1 \text { hasil karya yang } \\
\text { dibuat dengan }\end{array}$ & 4 & $13 \%$ \\
\hline
\end{tabular}




\begin{tabular}{|c|c|c|c|}
\hline Skor & Kriteria Penilaian & Frekuensi & Persentase \\
\hline & bantuan guru & & \\
\hline 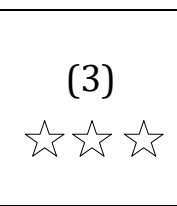 & $\begin{array}{l}\text { Anak mampu } \\
\text { memberi nama untuk } \\
1 \text { hasil karya yang } \\
\text { dibuat secara mandiri }\end{array}$ & 3 & $10 \%$ \\
\hline $\begin{array}{l}\text { (4) } \\
\text { (4) }\end{array}$ & $\begin{array}{l}\text { Anak mampu } \\
\text { memberi nama untuk } \\
\text { lebih dari } 1 \text { hasil } \\
\text { karya yang dibuat } \\
\text { secara mandiri }\end{array}$ & 20 & $67 \%$ \\
\hline
\end{tabular}

Pada variabel perkembangan kreativitas anak indikator 5: mayoritas anak mendapatkan skor 4 yaitu sebanyak 20 anak (67\%) yang berarti mayoritas anak mampu memberi nama untuk lebih dari 1 hasil karya yang dibuat secara mandiri.

\section{Pembahasan}

Berdasarkan hasil penelitian menunjukkan bahwa profil perkembangan motorik halus anak kelompok B TK Negeri Pembina Probolinggo berkategori sangat baik atau ( 3 is 4 ). Hal ini tampak pada bahwa terdapat mayoritas

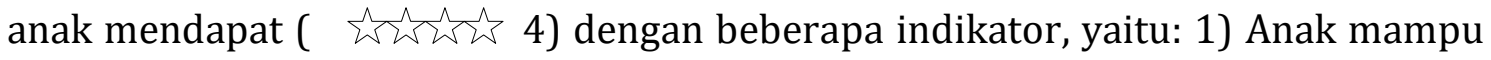
menekan 2 benda atau lebih secara mandiri/ anak mampu menusuk 2 pisang atau lebih dengan tusuk sate secara melintang dengan mandiri; 2) Anak mampu menggerakkan alat untuk memotong lebih dari 1 benda secara mandiri/ Anak mampu menggerakkan pisau untuk memotong lebih dari 1 potongan keju secara mandiri; 3) Anak mampu memegang 2 jenis bendaatau lebih tanpa bantuan guru; 4) Anak mampu menggerakkan 5 jari (lebih dari 5 gerakan) untuk meremas choco crunch tanpa bantuan guru; 5) Anak mampu menyusun benda menggunakan kedua tangan secara sejajar dengan rapi tanpa bantuan guru. Hal tersebut sesuai dengan pendapat (Sujiono, 2009). Gerakan motorik halus apabila gerakan hanya melibatkan bagian-bagian tubuh tertentu saja dan dilakukan oleh otot-otot kecil, seperti keterampilan menggunakan jari-jemari tangan atau gerakan pergelangan tangan yang tepat.

Sedangkan profil perkembangan kreativitas anak kelompok B TK Negeri Pembina Probolinggo juga berkategori sangat baik. Hal ini tampak pada bahwa terdapat mayoritas anak mendapat ( 250,54 ) dengan beberapa indikator, yaitu 1) Anak menemukan lebih dari 1 ide untuk menghasilkan suatu karya secara mandiri; 2) Anak mampu membuat lebih dari 1 bentuk menggunakan benda yang disediakan secara 


\section{Ika Anggraheni}

mandiri; 3) Anak mampu menghias bentuk dengan kombinasi lebih dari 2 bahan (media) secara mandiri; 4) Anak mampu menciptakan lebih dari 1 karya yang berbeda dari temannya secara mandiri; indikator 5 anak mampu memberi nama untuk lebih dari 1 hasil karya yang dibuat secara mandiri. Hal tersebut sesuai dengan pendapat (Satyadharma, 2012). Kegiatan cooking class merupakan kegiatan pembelajaran memasak tanpa menggunakan api yang dapat dilakukan oleh anak secara menyenangkan. Dalam penelitian yang dilakukan dengan hasil berdasarkan paparan yang ada ketika anak melakukan kegiatan cooking class juga dapat bermanfaat: a) untuk mengenalkan bahan makanan, kandungan gizi dan manfaatnya untuk tumbuh kembang anak-anak; b) melatih motorik halus anak; dan c) mengembangkan kreativitas anak melalui menghias piring saji sesuai dengan kreasi anak.

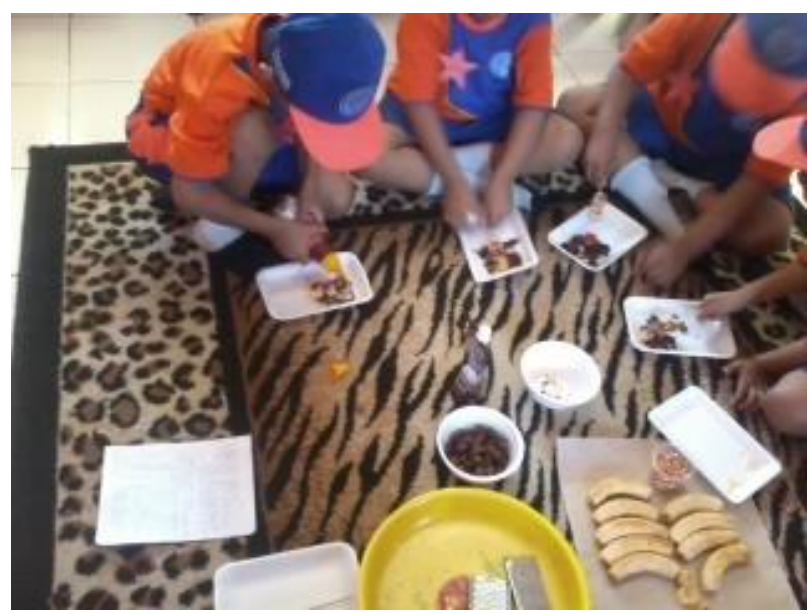

Gambar 1. Kegiatan cooking class pada saat anak memberi topping di TK Negeri Pembina

\section{Simpulan}

Berdasarkan hasil penelitian yang tersebut, dapat disimpulkan bahwa profil perkembangan motorik halus anak kelompok B TK Negeri Pembina Probolinggo, dalam kategori sangat baik ( kelompok B TK Negeri Pembina Probolinggo juga berkategori sangat baik ( ivisis 4).

Adapun Manfaat dari kegiatan cooking class antara lain dapat mengenalkan bahan makanan, kandungan gizi dan manfaatnya untuk tumbuh kembang anak-anak melatih motorik halus anak dan mengembangkan kreativitas anak melalui menghias piring saji sesuai dengan kreasi anak. 


\section{Daftar Rujukan}

Bronson, P. \& M. (2010). The creativity crisis. Retrieved from http://www.newsweek.com/creativity-crisis-74665.

Bruce, T. (2004). Cultivating creativity in babies, toddlers, and young children. London: Hodder Arnold.

Cambridgeshire Community Services NHS. (2018). Fine Motor Skills Children's Therapy Services. Retrieved from https://www.cambscommunityservices.nhs.uk

Depdiknas. (2009). Permendiknas Nomor 58 Tahun 2009 Tentang Standar Pendidikan Anak Usia Dini. Jakarta: Depdiknas.

Hamilton, J. (2019). The Many Benefits of Cooking with Preschool-Aged Children. Retrieved from https://www.brighthubeducation.com/pre-k-and-k-lessonplans/129263-cooking-in-preschool-why-we-should-do-it/

Satyadharma, D. R. (2012). Cooking is Fun Memasak Tanpa Api. Jakarta: Grasindo. Sujiono, N. Y. (2009). Konsep Dasar Pendidikan Anak Usia Dini. Jakarta: PT Indeks Jakarta. 